\title{
PENILAIAN KEPUASAN PENGGUNA TERHADAP ATRIBUT PRODUK DENGAN MENGGUNAKAN MODEL KANO; STUDI KASUS DESAIN INKUBATOR BAYI
}

\author{
UKURTA TARIGAN ${ }^{1}$, ROSNANI GINTING ${ }^{2}$ \\ Dosen Departemen Teknik Industri ${ }^{1,2}$ \\ Fakultas Teknik, Universitas Sumatera Utara \\ Medan 20155 \\ Email : ukurta.tarigan@yahoo.co.id \\ Email : rosnani_usu@yahoo.co.id
}

\begin{abstract}
Abstrak. A Newborns need special attention because it takes time to adapt to the outside world. In accordance with the standard post-neonatal procedures, newborns should be incorporated into the incubator within a certain period of time according to the infant's health level. Infant incubator as a medical device used to care for newborns, often get complaints from doctors and child nurses. The complaint indicates consumer dissatisfaction with infant incubator products in the hospital. Broadly speaking, complaints against infant incubators lie in inappropriate designs. To overcome these complaints the researchers apply the method of Kano to determine the satisfaction frome every technical characteristics. Through the mapping can be seen that from the seven attributes that become the question, there are two attributes that are in the category of Attractive namely "Additional Functions on Infant Incubator the Place Tube Oxygen" and "Size Door Holes is $15 \mathrm{~cm}$ ". There is one attribute that is in the One Dimensional category that is "Infant Incubator Price Rp 10.000.000". While the four attributes are in the category Must be "Infant Incubator Dimension $70 \mathrm{~cm}$ x $50 \mathrm{~cm} \mathrm{x} 40 \mathrm{~cm}$ ", "The distance of the floor from the base of the compartment $100 \mathrm{~cm}$ ", "Compartment infant incubator materials are Acrylic" and "The position of the controller on the infant incubator is in top right side ".
\end{abstract}

Keyword. Infant Incubator, QFD, Kano's Model, Product Design 


\section{Pendahuluan}

Berdasarkan data World Health Organization (WHO) angka kelahiran di Indonesia pada tahun 2012 mencapai 4,7 juta per tahun sedangkan angka kematian neonatal (baru lahir) mencapai angka 72 ribu bayi per tahun. Kematian bayi baru lahir (neonatal) pada umumnya disebabkan oleh prematuritas, berat badan bayi lahir rendah, infeksi, asfiksia dan trauma lahir [1].

Dokter dan perawat bagian anak memiliki keluhan-keluhan dalam penggunaan infant incubator yang terdapat di rumah sakit. Keluhankeluhan ini dikumpulkan dari penyebaran kuesioner pendahuluan kepada dokter dan perawat bagian anak, diantaranya meliputi harga, desain, serta perawatan. Keluhan-keluhan yang diperoleh tersebut menunjukkan adanya ketidakpuasan dokter dan perawat bagian anak terhadap infant incubator yang tersedia. Ketidakpuasan tersebut tentunya akan berpengaruh terhadap penurunan kinerja dokter dan perawat maupun kualitas pelayanan yang ditawarkan oleh RSU.

Berdasarkan permasalahan tersebut dilakukan pendekatan penerapan Model KanoPendekatan Model Kano mengindikasikan pengembangan produk harus memahami respon karakteristik teknis dengan memeriksa teknis karakteristik untuk pelanggan dalam bentuk survei pelanggan menggunakan kuesioner Kano. Model Kano digunakan agar dapat diketahui atribut yang menjadi keunggulan dan kelemahan sesuai dengan keinginan pelanggan terhadap suatu produk.

Desain produk merupakan hal yang sangat penting dalam bidang manufaktur. Desain produk yang baik akan dapat meningkatkan jumlah dan harga jual dari produk, sehingga dapat meningkatkan keuntungan secara optimal. Akan tetapi, desain produk yang gagal mengakibatkan produk tidak terjual di pasaran. Hal ini, akan menimbulkan kerugian tidak hanya dibidang desain saja, bidang yang lain pun akan terkena imbasnya.

\section{Bahan dan Metode Penelitian \\ 2.1 Landasan Teori}

Konsultan TQM di Jepang Noriaki Kano, telah memberikan model yang sangat berguna mengenai kepuasan pelanggan yang berkaitan dengan karakteristik produk .Menggunakan karakteristik istilah yang tepat di kemudian hari, dan kita akan menggambar perbedaan yang tajam antara kebutuhan pelanggan dan karakteristik produk . Untuk saat ini menggunakan karakteristik istilah untuk merujuk pada fitur atau kemampuan suatu produk .

Karakteristik produk Model Kano terbagi menjadi tiga kategori yang berbeda yang masingmasing mempengaruhi pelanggan dengan cara yang berbeda . Ketiga kategori tersebut adalah:

1. Tidak Puas (Dissatisfiers), juga dikenal sebagai karakteristik "Must be" , "Basic" atau "Expected"
2. Pemuas (Satisfiers), juga dikenal sebagai karakteristik "One-Dimensional" , atau "Straight Line "

3. Menyenangkan (Delighter), juga dikenal sebagai karakteristik "Attractive" atau "Exciting"

Sumbu horizontal di diagram menunjukkan kinerja aktual atau keadaan pemenuhan fisik dalam memberikan masingmasing kategori karakteristik produk tersebut kepada pelanggan, sedangkan sumbu vertikal menunjukkan tingkat terhadap kepuasan pelanggan. Sebuah musuh strategi bersaing mengembangkan produk dan layanan harus memperhitungkan kategori-kategori theree karakteristik produk. Ini harus menentukan apa tingkat saat ini kepuasan untuk masing-masing kategori tehse dan, harus memutuskan apa proporsi sumber daya proyek untuk mengalokasikan ke produk atau jasa karakteristik pada masing-masing kategori

N. Kano telah mengembangkan diagram berguna untuk mencirikan kebutuhan pelanggan. Menurut model Kano, atribut pelanggan dapat secara efektif dikategorikan menjadi enam kategori , dijelaskan di bawah ini :

1. Attractive : Sebuah atribut kualitas tertentu dapat berasal kepuasan besar di pelanggan. Namun, tidak adanya atribut kualitas yang sama tidak berasal ketidakpuasan. Tingkat kepuasan pelanggan akan meningkat sangat tinggi dengan meningkatnya kinerja atribut. Akan tetapi penurunan kinerja atribut tidak akan menyebabkan penurunan tingkat kepuasan.

2. Must Be : Pelanggan tidak akan puas ketika kualitas saat ini atribut memenuhi. Namun, jika produk atau jasa tidak memenuhi kebutuhan pelanggan, pelanggan akan menjadi sangat tidak puas. Tetapi kepuasan pelanggan tidak akan meningkat jauh diatas netral meskipun kinerja dari atribut tersebut tinggi.

3. One-Dimensional : Tingkat kepuasan pelanggan berbanding lurus dengan atribut kualitas tertentu. Semakin tinggi kualitas satu dimensi elemen, kepuasan pelanggan yang lebih tinggi akan dan sebaliknya . Dengan demikian, pelanggan biasanya dan secara eksplisit menuntut persyaratan satu dimensi.

4. Indefferent : Sebuah kualitas tertentu yang tidak berpengaruh pada kepuasan pelanggan apakah atribut kualitas hadir atau tidak

5. Reverse : Apabila tingkat kepuasan pelanggan berbanding terbalik dengan hasil kinerja atribut

6. Questionable : Karena kesalahpahaman atau salah tafsir dari jawaban pada survey atau mengisi kuesioner kesalahan . apabila tingkat kepuasan pelanggan tidak dapat didefinisikan (terdapat kontradiksi pada jawaban pelanggan) 
Menurut kategori Kano, tim pengembangan produk harus memahami karakteristik teknis respon mereka. Mereka harus memeriksa karakteristik respon teknis dengan meminta mereka untuk pelanggan mereka dalam bentuk survei pelanggan menggunakan kuesioner Kano . Kuesioner Kano terdiri dari dua pertanyaan kali lipat, pertanyaan fungsional dan pertanyaan disfungsional. Pertanyaan Fungsional meminta sikap pelanggan jika respon teknis yang berfungsi dengan baik. Jika tidak, pertanyaan disfungsi nasional adalah pertanyaan yang menanyakan persepsi pelanggan jika respon teknis tidak bekerja atau tidak ada. Kategori respon teknis dapat ditentukan dengan mempertimbangkan kombinasi jawaban pelanggan.

Pemilihan respon teknis harus mempertimbangkan beberapa faktor selain koefisien di atas, seperti biaya, waktu, dan tujuan perusahaan. Pemilihan respon teknis melibatkan model matematika untuk mengoptimalkan hasil yang diharapkan. Respon teknis yang dipilih akan menjadi persyaratan desain produk.

\subsection{Metode Penelitian}

Data-data primer dikumpulkan dengan cara pengamatan atau pengukuran langsung, antara lain data kuesioner pendahuluan, data kuesioner terbuka, data kuesioner tertutup, data kuesioner karakteristik teknis. data kuesioner hubungan antar karakteristik teknis dan data kuesioner mengenai part kritis serta data kuesioner hubungan antar part kritis. Data sekunder diperoleh berdasarkan data yang diperoleh dari hasil wawancara dengan supplier produk, antara lain data part pemyusun dan biaya.

Pada penelitian ini metode pengumpulan data adalah sebagai berikut:

1. Teknik observasi, yaitu melakukan pengamatan langsung mengenai proses penggunaan infant Incubator.

2. Teknik Survey, yaitu teknik untuk mendapatkan data primer yang dibutuhkan berkaitan dengan kebutuhan konsumen terhadap produk infant incubatordengan menyebarkan kuesioner.

3. Teknik dokumentasi, yaitu dengan mengumpulkan data mengenai karakteristik produk infant incubator pada perusahaan supplier.

4. Studi literatur, yaitu sebagai landasan awal terhadap permasalahan serta sebagai variabel penyusun kuesioner.

Variabel-variabel yang akan dipertanyakan kepada konsumen dibuat berdasarkan hasil kuesioner pendahuluan yang menanyakan tentang keluhan dokter dan perawat terhadap infant incubator. Variabel terhadap infant incubator disesuaikan dengan keluhan dan literatur.

Populasi yang diambil adalah semua dokter dan perawat bagian anak yang bertugas di sebuah rumah sakit di Kota Medan, Sumatera Utara.
Penelitian dilakukan pada semua elemen populasi karena subjeknya yang relatif sedikit atau disebut dengan penelitian populasi. Hal tersebut berlaku dalam pengumpulan data menggunakan kuesioner pendahuluan, kuesioner terbuka dan kuesioner tertutup. Metode sampel yang digunakan adalah Purposive Sampling.

Tahapan pengolahan data diawali dengan mengumpulkan data dari penyebaran kuesioner terbuka sehingga diperoleh modus yang akan digunakan untuk kuesioner tertutup. Hasil kuesioner tertutup kemudian dituangkan kedalam penilaian tingkat kepentingan yang diuji validitas dan reliabilitasnya.

\section{Hasil dan Pembahasan}

Pengumpulan data dilakukan dengan teknik penyebaran kuesioner kepada responden. Kuesioner dibagikan dalam 2 tahapan, tahapan pertama merupakan kuesioner terbuka. Kuesioner ini merupakan bentuk pertanyaan yang diajukan kepada 35 responden tentang penilaian harapan operator infant incubator (dokter dan perawat bagian anak).

Jawaban responden yang tertuang pada kuesioner terbuka menghasilkan beberapa modus yang menjadi pendukung atribut pertanyaan pada kuesioner tahap kedua, yaitu kuesioner tertutup. Responden pada kuesioner tertutup ini berjumlah 63 responden dokter dan perawat bagian anak. Penentuan jumlah responden ini berdasarkan metode sampling yang digunakan dalam penelitian yaitu total sampling (penelitian populasi). Kuesioner derajat kepentingan atribut pertanyaan menggunakan skala likert 1- 5. Data dari derajat kepentingan ini digunakan untuk mengetahui derajat kepentingan antar atribut.

Pengujian validitas derajat kepentingan, model kano dan tingkat kepuasan menggunakan persamaan korelasi product moment (Pearson). Sebelum melakukan perhitungan validitas data dari kuesioner derajat kepentingan dalam skala Likert yang berupa skala ordinal terlebih dahulu diubah menjadi skala interval dengan menggunakan Method of Successive Interval (MSI). Selanjutnya, nilai-nilai dari skala interval baru tersebut diuji validitasnya.

Tabel 1. Hasil Perhitungan Validitas Derajat Kepentingan

\begin{tabular}{|c|c|c|c|l|}
\hline Atribut & $\begin{array}{l}\text { Koef. } \\
\text { Korelasi }\end{array}$ & $\begin{array}{l}\mathbf{r} \\
\text { Tabel }\end{array}$ & $\mathbf{N}$ & Ket. \\
\hline 1 & 0.530 & 0.334 & 35 & Valid \\
\hline 2 & 0.658 & 0.334 & 35 & Valid \\
\hline 3 & 0.627 & 0.334 & 35 & Valid \\
\hline 4 & 0.532 & 0.334 & 35 & Valid \\
\hline 5 & 0.712 & 0.334 & 35 & Valid \\
\hline 6 & 0.527 & 0.334 & 35 & Valid \\
\hline 7 & 0.390 & 0.334 & 35 & Valid \\
\hline
\end{tabular}

Tabel 1 dapat dilihat koefisien korelasi product moment semuanya berada di atas 0.334 maka dapat disimpulkan bahwa atribut pertanyaan 
pada kuesioner adalah valid atau dengan kata lain terdapat konsistensi internal dalam variabel tersebut.

Tabel 2. Hasil Perhitungan Validitas Model Kano

\begin{tabular}{|l|l|l|l|l|}
\hline Atribut & $\begin{array}{l}\text { Koef. } \\
\text { Korelasi }\end{array}$ & $\mathbf{r}$ Tabel & $\mathbf{N}$ & Ket. \\
\hline 1 & 0.499 & 0.334 & 35 & Valid \\
\hline 2 & 0.527 & 0.334 & 35 & Valid \\
\hline 3 & 0.378 & 0.334 & 35 & Valid \\
\hline 4 & 0.763 & 0.334 & 35 & Valid \\
\hline 5 & 0.508 & 0.334 & 35 & Valid \\
\hline 6 & 0.419 & 0.334 & 35 & Valid \\
\hline 7 & 0.373 & 0.334 & 35 & Valid \\
\hline
\end{tabular}

Dari tabel 2. dapat dilihat koefisien korelasi product moment semuanya berada di atas 0.334 , maka dapat disimpulkan bahwa atribut pertanyaan pada kuesioner model Kano adalah valid atau dengan kata lain terdapat konsistensi internal dalam variabel tersebut.

Tabel 3 Hasil Perhitungan Validitas Kepuasan Konsumen

\begin{tabular}{|l|l|l|l|l|}
\hline Atribut & $\begin{array}{l}\text { Koef. } \\
\text { Korelasi }\end{array}$ & $\begin{array}{l}\mathbf{r} \\
\text { Tabel }\end{array}$ & $\mathbf{N}$ & Ket. \\
\hline 1 & 0.703 & 0.334 & 35 & Valid \\
\hline 2 & 0.659 & 0.334 & 35 & Valid \\
\hline 3 & 0.368 & 0.334 & 35 & Valid \\
\hline 4 & 0.501 & 0.334 & 35 & Valid \\
\hline 5 & 0.595 & 0.334 & 35 & Valid \\
\hline 6 & 0.368 & 0.334 & 35 & Valid \\
\hline 7 & 0.799 & 0.334 & 35 & Valid \\
\hline
\end{tabular}

Tabel 3. dapat dilihat koefisien korelasi product moment semuanya berada di atas 0.334 maka dapat disimpulkan bahwa atribut pertanyaan pada kuesioner kepuasan konsumen adalah valid atau dengan kata lain terdapat konsistensi internal dalam variabel tersebut.

Pengujian reliabilitas untuk data tingkat kepentingan, model kano dan tingkat kepuasan dilakukan untuk mengetahui kuesioner yang telah dibuat reliabel atau tidak.

Tabel 4 Perhitungan Varians Tingkat Kepentingan

\begin{tabular}{|l|l|}
\hline Butir & Varians \\
\hline 1 & 0.7169 \\
\hline 2 & 0.9357 \\
\hline 3 & 0.8610 \\
\hline 4 & 0.5855 \\
\hline 5 & 0.8323 \\
\hline 6 & 0.6575 \\
\hline 7 & 0.7437 \\
\hline
\end{tabular}

Dimasukkan ke rumus Alpha $r=\left(\frac{k}{k-1}\right)\left(1-\frac{\sum \sigma_{b}^{2}}{\sigma_{t}^{2}}\right)$

Nilai koefisien reliabilitas kinerja sebesar 0.6546

Terdapat 2 cara untuk menilai apakah suatu instrument memiliki tingkat reliabilitas yang tinggi, yaitu:

a. Instrumen memiliki tingkat reliabilitas yang tinggi jika nilai koefisien yang diperoleh $>0.60$

b. Dari tabel kritis koefisien korelasi $r$ Pearson.

Dari tabel kritis koefisien korelasi rPearson untuk taraf signifikan 5\%, dengan jumlah responden 35 diperoleh nilai kritis sebesar 0.334 . Nilai $r$ hitung $>0.60$ dan $r$ hitung $>\mathrm{r}$ tabel, maka data dinyatakan reliabel, maka dapat disimpulkan bahwa kuesioner dapat dipercaya kebenaran datanya.

Tabel 5. Perhitungan Varians Model Kano

\begin{tabular}{|l|l|}
\hline Butir & Varians \\
\hline 1 & 0.7520 \\
\hline 2 & 0.8794 \\
\hline 3 & 0.8838 \\
\hline 4 & 1.1033 \\
\hline 5 & 1.1767 \\
\hline 6 & 0.8491 \\
\hline 7 & 0.5199 \\
\hline
\end{tabular}

Dimasukkan ke rumus Alpha, maka nilai koefisien reliabilitas kinerja sebesar 0.5021. Dari tabel kritis koefisien korelasi rPearson untuk taraf signifikan 5\%, dengan jumlah responden 35 diperoleh nilai kritis sebesar 0.334

Karena nilai $\mathrm{r}$ hitung $>\mathrm{r}$ kritis, maka data dinyatakan reliabel, maka dapat disimpulkan bahwa kuesioner dapat dipercaya kebenaran datanya.

Tabel 6. Perhitungan Varians Kepuasan Konsumen

\begin{tabular}{|l|l|}
\hline Butir & Varians \\
\hline 1 & 0.8087 \\
\hline 2 & 1.0440 \\
\hline 3 & 0.6611 \\
\hline 4 & 0.7584 \\
\hline 5 & 1.0113 \\
\hline 6 & 0.9884 \\
\hline 7 & 0.6767 \\
\hline
\end{tabular}

Dari tabel kritis koefisien korelasi rPearson untuk taraf signifikan 5\%, dengan jumlah responden 35 diperoleh nilai kritis untuk taraf signifikan 5\% sebesar 0.334 . Nilai $r$ hitung $>r$ kritis, maka data dinyatakan reliabel, maka dapat 
disimpulkan bahwa kuesioner dapat dipercaya kebenaran datanya

Hasil survei menggunakan kuesioner kano diolah untuk menentukan kategori setiap atribut bedasarkan model kano. Pengolahan hasil survei model kano secara tradisional dihitung jumlah atau nilai masing-masing kano pada tiap-tiap atribut terhadap semua responden. Jumlah nilai kategori kano setiap atribut terhadap semua responden yang telah diperoleh selanjutnya ditentukan kategori Kano tiap atribut dengan menggunakan Blauth's formula.

1. Jumlah nilai (one dimensional + attractive + must be) >jumlah nilai (indiferent + reverse + questionable) maka grade yang diperoleh adalah nilai yang paling maksimum dari (one dimensional,attractive,must be)

2. Jumlah nilai (one dimensional + attractive + must be) <jumlah nilai (indifferent + reverse + questionable) maka grade yang diperoleh adalah nilai yang paling maksimum dari (indifferent, reverse, questionable).

3. Jumlah nilai (one dimensional + attractive + must be) $=$ jumlah nilai (indifferent + reverse + questionable) maka gradediperoleh adalah nilai yang paling maksimum diantara semua kategori kanoyaitu (one dimensional, attractive, must be dan indifferent,reverse, questionable ).

Hasil perhitungan dan analisa pengklasifikasian kategori Kano yang diperoleh dapat digunakan untuk pemetaan kategori Kano tiap atribut keinginan konsumen (CR) terhadap semua responden yang dapat dilihat pada Tabel 7 .

Tabel 7 Pemetaan Kategori Kano Tiap Atribut

\begin{tabular}{|l|l|l|l|l|l|l|l|}
\hline \multirow{2}{*}{ No } & \multirow{2}{*}{ Atribut } & \multicolumn{3}{|c|}{ Kategori Kano } & \\
\cline { 3 - 8 } 1 & & $\mathbf{A}$ & $\mathbf{O}$ & $\mathbf{M}$ & $\mathbf{I}$ & $\mathbf{R}$ & $\mathbf{Q}$ \\
\hline & $\begin{array}{l}\text { Dimensi Infant } \\
\text { Incubator 70 cm x 50 } \\
\text { cm x 40 cm }\end{array}$ & 18 & 5 & $\mathbf{2 2}$ & 18 & 0 & 0 \\
\hline 2 & $\begin{array}{l}\text { Jarak lantai dari dasar } \\
\text { compartment } 100 \mathrm{~cm}\end{array}$ & 14 & 9 & $\mathbf{1 7}$ & 19 & 4 & 0 \\
\hline 3 & $\begin{array}{l}\text { Bahan compartment } \\
\text { infant incubator yaitu } \\
\text { Acrylic }\end{array}$ & 12 & 2 & $\mathbf{2 2}$ & 23 & 4 & 0 \\
\hline 4 & $\begin{array}{l}\text { Fungsi Tambahan } \\
\text { pada infant incubator } \\
\text { yaitu Tempat Tabung } \\
\text { Oksigen }\end{array}$ & $\mathbf{2 0}$ & 8 & 10 & 21 & 4 & 0 \\
\hline 5 & $\begin{array}{l}\text { Ukuran lubang pintu } \\
\text { yaitu 15 cm }\end{array}$ & $\mathbf{2 0}$ & 8 & 16 & 15 & 0 & 4 \\
\hline 6 & $\begin{array}{l}\text { Harga infant } \\
\text { incubator } \text { Rp } \\
\text { 10.000.000 }\end{array}$ & 14 & $\mathbf{1 9}$ & 13 & 13 & 4 & 0 \\
\hline 7 & $\begin{array}{l}\text { Posisi controller pada } \\
\text { infant incubator } \\
\text { berada di samping } \\
\text { kanan atas }\end{array}$ & 7 & 18 & $\mathbf{2 0}$ & 18 & 0 & 0 \\
\hline
\end{tabular}

Hal yang dilakukan setelah memperoleh jumlah/ nilai kategori Kano tiap-tiap atribut terhadap semua responden maka dilakukan penentuan kategori Kano dengan menggunakan rumus Blauth's formula. Misalnya untuk atribut 1 (one dimensional + attractive + must be $)=25$ dan $($ indifferent + reverse + questionable $)=10$ sehingga kategori Kano untuk atribut 1 adalah $\mathbf{M u s t}$
Be (M). Rekapitulasi Kategori Kano dapat dilihat pada Tabel 8.

Tabel 8. Pemetaan Kategori Kano Tiap Atribut Menurut Blauth's formula

\begin{tabular}{|c|l|c|}
\hline No & \multicolumn{1}{|c|}{ Atribut } & $\begin{array}{c}\text { Kategori } \\
\text { Kano }\end{array}$ \\
\hline 1 & $\begin{array}{l}\text { Dimensi Infant Incubator } 70 \\
\text { cm x } 50 \mathrm{~cm} \text { x } 40 \mathrm{~cm}\end{array}$ & $\mathrm{M}$ \\
\hline 2 & $\begin{array}{l}\text { Jarak lantai dari dasar } \\
\text { compartment } 100 \mathrm{~cm}\end{array}$ & $\mathrm{M}$ \\
\hline 3 & $\begin{array}{l}\text { Bahan compartment infant } \\
\text { incubator yaitu Acrylic }\end{array}$ & $\mathrm{M}$ \\
\hline 4 & $\begin{array}{l}\text { Fungsi Tambahan pada infant } \\
\text { incubator yaitu Tempat } \\
\text { Tabung Oksigen }\end{array}$ & $\mathrm{A}$ \\
\hline 5 & $\begin{array}{l}\text { Ukuran lubang pintu yaitu } 15 \\
\text { cm }\end{array}$ & $\mathrm{A}$ \\
\hline 6 & $\begin{array}{l}\text { Harga infant incubator Rp } \\
\text { 10.000.000 }\end{array}$ & $\mathrm{M}$ \\
\hline 7 & $\begin{array}{l}\text { Posisi controller pada infant } \\
\text { incubator berada di samping } \\
\text { kanan atas }\end{array}$ \\
\hline
\end{tabular}

Tabel 8 dapat dilihat bahwa terdapat 2 atribut yang berada pada kategori Attractive, 1 atribut yang berada pada kategori One dimensional, dan 4 atribut yang berada pada kategori Must be.

\section{Kesimpulan dan Saran}

Bayi baru lahir membutuhkan perhatian khusus karena diperlukan waktu untuk beradaptasi dengan dunia luar. Prosedur standar pasca neonatal mengatakan bahwa bayi baru lahir harus dimasukkan ke dalam inkubator dalam jangka waktu tertentu sesuai dengan tingkat kesehatan bayi tersebut. Infant incubator adalah salah satu peralatan medis yang digunakan untuk membantu bayi beradaptasi dengan dunia luar terutama dalam hal perbedaan suhu [9]

Karakteristik teknis yang menjadi output pada fase I adalah Ergonomy, Cost, User Friendly, Features, Safe Operation, Durability dan Aesthetics. Pembangunan Quality Function Deployment Fase I menghasilkan ukuran kinerja karakteristik teknis yaitu tingkat kesulitan, derajat kepentingan dan perkiraan biaya. Karakteristik teknis Ergonomy, Cost dan Use Friendly memiliki tingkat kesulitan, derajat kepentingan dan perkiraan biaya yang terbesar sehingga menjadi prioritas perbaikan. Sementara atribut produk yang menjadi prioritas perbaikan berdasarkan planning matrix dari QFD Fase I adalah Fungsi Tambahan pada Infant Incubator yaitu Tempat Tabung Oksigen serta Bahan compartment infant incubator yaitu Acrylic.

\section{DAFTAR PUSTAKA}

Ghozali, Imam. 2002. Aplikasi Analisis Multivariat dengan Program SPSS. Semarang: Badan Penerbit Universitas Dipenogoro. 
Cohen, Lou. 1995. Quality Function Deployment : How to Make QFd Work for You .USA : Addison-Wesley Publishing Company. pp 123

Day, Ronald. G. 1993. Quality Function Deployment, Linking a Company with Its Costumers. Milwaukee : ASQC Quality Press.

Gea Medical. Operator's Manual YP-100 Infant Incubator.

Ginting, Rosnani. 2010. Perancangan Produk .Yogyakarta: Graha Ilmu. hal 135-137.

Jaiswal, E. 2012. A Case Study on Quality Function Deployment. India: Mewar University. hal 2-4.

Leah Tholosa, Theresa Good, et all. 2014. Designing a Low-Cost Multifunctional Infant Incubator. Journal of the Association for Laboratory Automation . April 2014. Impact Factor: 1.5 • DOI: 10.1177/2211068214530391 · Source: PubMed

Nagamachi, M., 1991. An image technology expert system and its application to design consultation. International Journal of Human-Computer Interaction 3(3), 267279.

Nagamachi, M., (1995). KANO: A New Ergonomic Consumer-Oriented Technology For Product Development. International Journal of Industrial Ergonomics 15, 3-11.

Nagamachi. M. and Imada, A.S., (1995). KANO: An Ergonomic Technology For Product Development. International Journal of Industrial Ergonomics 15, 1.
Nagamachi, M., (1997). KANO: The Framework And Methods. In: M. Nagamachi (Ed.), KANO 1. Kure: Kaibundo Publishing, 1-9.

Nagamachi, M., (1999). KANO: the implication and applications to product development. IEEE Systems, Man, and Cybernetics (SMC) International Conference Proceedings 6, 273-278.

Nagamachi, M., (2001). KANO. Workshop on International Conference on Affective Human Factors Design, Singapore.

Nagamachi, M., (2002a). KANO In Consumer Product Design. Ergonomics in Design The Quarterly of Human Factors Applications, 10(2), 5-9.

Nagamachi, M., (2002b). KANO As A Powerful Consumer-Oriented Technology For Product Development. Applied Ergonomics 33, 289-294.

Nurlandi, F 2010 Desain Inkubator Bayi dengan Kontrol Otomatis yang Ekonomis untuk Klinik Persalinan (Ecobator) (Surabaya: ITS)

Otto, K and Wood K 2001 Product Design (London: Prentice Hall)

WHO Statistics [Cited 2015] World Health Statistics 2014 [Internet] available from http://who.int/gho/publications/world_heal th_statistics/2014/en/

World Health Organization [cited 2014] Medical Devices [Internet] available from http://www.who.int/medical_devices /innovation/en/ 